\title{
Intercultural Work Environment and Leadership Style
}

\author{
${ }^{1}$ Lubomira Strazovska, ${ }^{2}$ Rozalia Sulikova \\ ${ }^{1,2}$ Comenius University in Bratislava, Faculty of Management, Slovak Republic
}

\begin{tabular}{|c|c|}
\hline & ABSTRACT \\
\hline $\begin{array}{l}2019 \text { Research Leap/Inovatus Services Ltd. } \\
\text { All rights reserved. } \\
\text { DOI: } 10.18775 / \text { jibrm.1849-8558.2015.46.3003 } \\
\text { URL: } \underline{\text { http://dx.doi.org/10.18775/jibrm.1849- }} \\
\text { 8558.2015.46.3003 }\end{array}$ & \multirow{2}{*}{$\begin{array}{l}\text { The global environment of organizations requires from management to respond promptly to the } \\
\text { demands of a changing environment, both external and internal, requiring managers to continually } \\
\text { develop their skills, especially in the area of soft skills. The current management of organizations, } \\
\text { in an effort to make the most of their employees' potential, seeks to promote an individual approach } \\
\text { to their motivation, expresses an increased interest in employee satisfaction and loyalty, encourages } \\
\text { employee involvement in achieving organization goals, seeks to apply W-L-B and more. This } \\
\text { requires managers to have a high level of social skills and an appropriate leadership style that } \\
\text { considers both the needs of the individual and his cultural background. Highly productive } \\
\text { employees are the key to success for all organizations, they are the key to a competitive advantage } \\
\text { in the global business world. At present, there is a strong pressure on organizations to behave in the } \\
\text { spirit of corporate social responsibility both by senior staff and by the general public. Highly } \\
\text { required is a style of leadership that honors basic ethical principles in any country. It should be } \\
\text { stressed that there are still organizations that do not respect, for example, the need for ethical } \\
\text { leadership, ethical decision-making at all levels of management and all employees. The aim of the } \\
\text { paper is to point to preferred leadership styles especially in the younger generation, helping to } \\
\text { increase their job satisfaction and productivity, as well as those of managers who will support this } \\
\text { effort in a culturally diverse environment. In the submitted analysis of the topic selected scientific } \\
\text { methods were applied such as e.g. a critical analysis and synthesis, comparison and deduction. }\end{array}$} \\
\hline $\begin{array}{l}\text { Keywords: } \\
\text { Intercultural work, Environment, Leadership } \\
\text { Style, Job satisfaction } 1\end{array}$ & \\
\hline
\end{tabular}

\section{Introduction}

In today's multicultural business environment, if organizations want be successful, they need to have a high level of flexibility, innovativeness and adaptability. Their representatives and managers at all levels of management must be able to effectively motivate subordinates with different cultural backgrounds to maximize their potential. This requires the ability to be a real leader who is capable of creating positive relationships with his followers. A much-needed prerequisite for this ability and therefore effective leadership is to have a high level of emotional (EI) and cultural intelligence (CI). According to Goleman (2002), the central task for all leaders is to build and maintain a solid relationship with others, to foster emotionally intelligent leadership. An individual approach, the ability to adapt motivational approaches to the needs of today's young generation and to adapt to an environment characterized by the cultural diversity of employees in one organization is important.

In Slovak conditions, in the past, no emphasis was placed on participatory management approach; companies have rarely introduced flexible approaches, working time, and remuneration system or career growth. This is part of the ambitious young people's demands for organizations and their management. Fitting reflection of the needs of employees from the generations $\mathrm{Y}$, in particular, will enable organizations not only to increase the motivation of existing employees but also to increase their attractiveness. According to Trelova and Olsavsky (2016) for example dual education implemented in organization can improve company image, support corporate culture, strength the social status of the company and improve the positive perception of the company in the region.

The younger generation (in our cultural conditions), when choosing an employer, places more and more emphasis on factors such as environmental protection, fairness, honesty, the possibility of co-decision, the opportunity to openly communicate and express their opinions, and so on. In their vision of an efficient manager, they put emphasis not only on expertise, but also on emotional and cultural competence, on moral maturity, appreciation for communication skills (especially the often-underestimated ability to listen), and openness to new ideas. Ethical behavior and an ethical culture plays a key role in the eyes of the emerging generation of 
managers. According to Roll (2014) among the millennials management technique that emphasize monetary rewards are becoming less relevant. Freedom, flexibility, development opportunity, learning and trust are preferred characteristics of the ideal workplace. Millennials believe that business should focus more on a societal purpose.

The use of participatory, transformational and ethical leadership in relation to employees opens up opportunities not only to gain and exploit the potential of the current young generation but also to retain young employees.

According to Marešova (2010) in a global environment, knowledge is also a key factor and therefore managers just have to look for ways to make the best use of them. This approach is considered to be key to addressing the challenge of getting and keeping those who are fit to reduce the likelihood that those who are most able to leave the organization will have to set up a path of creativity and innovation in the organization to succeed in a strong competitive struggle.

\section{Crucial Requirements on Managers in the Cultural Diverse Workplace}

According to the many authors and researches if managers want success in the global world, in the multicultural work environment they should dispose of intercultural competence. J. Stier (2006) suggests that intercultural competence can be divided into two categories: content- competences and processual competences. According to Goleman (2002) managers need to develop emotional intelligence (EI) in particular. He describes in this regard four competency clusters: self-awareness, self-management, social awareness, relationship management - cultural intelligence, cultural sensitivity and six leadership styles: Coercive, Authoritative, Affiliative, Democratic, Coaching, Pacesetting. Leaders who get the best results don't rely on just one leadership style; they use most of the styles. They should understand what style to use in which situation. Leaders who have mastered four or more styles have the very best climate and business performance (Goleman 2000).

To be more effective in leadership in multicultural work environment according to DuBrin (2010) the leaders should be aware of problems of cultural misunderstanding in 5 areas language differences, differences in religion, work habits, women's role, personal appearance and behaviour. In moving from domestic to global management, leaders have to develop an ability to select a pattern of behaviour best suitable to particular situation. Ability to quickly adopt and to be a flexible in their behaviour and thinking are not only the competitive advantage of managers but also the key condition of manager's success. Foundation for effective global manager creates according to Solomon, Schell (2009) these personal attributes: goal oriented tenacity, managing complexity, cultural sensitivity, emotional resilience, ability to form relationship.
Importance of the social skills emphasizes also Byrd (2007). According to this author, global leaders need to build their interpersonal skills to deal with racial conflicts that have occurred and to develop individuals and groups in the workplace. Gutierrez, Spencer, \& Zhu (2012) report that essential leadership skills that global leaders should possess are: self- awareness, appreciation of individual uniqueness, results-oriented, achievement driven and forward thinking. An outstanding cross-cultural leader thinks globally and leads locally, need to be able to sell the vision to employees by effectively communicating with employees, should be more visible and accessible to employees because of it can enhance the manager-employee relationship, increases productivity through positive organizational climate, open supportive working environment. Effective global leaders need to be able to establish trust, motivate team members and foster a team spirit. (Roy 2012). Great leaders should to understand the world through the people they lead; they must avoid assumptions, generalisation, and stereotypes. (Roll 2014).

Leaders in the culturally diverse workplace need to be able to manage settings efficiently, should support high performance, innovation, social responsibility, worker involvement, WorkLife-Balance. They should have not only high level of emotional but also high level of cultural intelligence (CI). CI is created by: (Thomas and Inkson 2003, p. 23)

- Knowledge - culturally intelligent manager requires knowledge about culture and basic principles of cross cultural interaction - what culture is, how culture varies and how it affects behaviour.

- Mindfulness - culturally intelligent manager practices mindfulness, ability to pay attention in a reflective and creative way to the stimulus that appears in intercultural situations

- Ability to choose appropriate behaviour form that is correct for different intercultural situation.

Very appreciated and desired qualities of managers are also adaptability, flexibility, willingness to listen and learn, openness and tolerance to differences, ability to build atmosphere of trust and responsibility, etc. They should be able to take advantage of the possible synergic effects, support such a model of thinking that avoids stereotypes, ethnocentrism and parochialism when conducting intercultural teams. In addition, effective managers do not get involved without effective communication skills.

The above-mentioned characteristics are linked to "soft skills", which are still not given enough attention by management and which are still underestimated in many organizations. It is necessary to emphasize that the concepts of an efficient manager and the requirements for his/her competence are different in different cultures. In order to better understand the impact of culture on behaviour, it is necessary to know how 
culture influences perception, interpersonal interactions, ways of communicating or decision-making and the value of the rankings, and more both in itself and in others. Hofstede (1980) and others, based on research on managers and employees of multinational organizations, identified several of the most important dimensions that have their reflection in the working attitudes and values of people in today's environment. These must be taken into account in both individual and team leadership. In the case of the management of a multicultural team, it is important to note the relationship between the manager and the team members' relationships with each other. The most frequently cited positives of multicultural teams include: creativity, flexibility, high tolerance level, multiple perspectives, inspiration, bridge building. On the other hand, there are even negative ones like, different expectations, communication problems and coordination.

(Solomon and Schell 2009). Meyer (2017) stresses that when selecting access to subordinates, it is also necessary to consider the approaches to authority and decision-making. Significant differences are in the communication style, how to give feedback, how to evaluate, how to convince, build trust, make decisions, and demonstrate the degree of respect for the superior and how to prove it. To achieve that managers are effective in a global environment requires their preparation and development. It is necessary to pay special attention to the development of self-knowledge and knowledge of others, the development of cultural sensitivity, and the effectiveness of intercultural communication, the management of stress situations and the understanding of the impact of cultural differences on behaviour.

\section{Preferred Leadership Styles}

Under the term leadership, we most commonly understand as influence of behavior of our superiors, which leads to the achievement of the organizational goal, while managers are expected to effectively apply managerial skills and abilities. In the literature, there are many definitions of the concept of leadership: Leadership is the influence of individuals and groups, the purpose of which is to direct their actions in order to be in line with the goals set by their leader (Schermerhorn 1991). "People's leadership is the process of applying the influence of the leader to the behavior of co-workers by changing their thinking and feeling in relation to certain organizational reality phenomena and directing their activities to meet the goals set." (Rudy et al. 2013, p. 2016).

Preferred style of leadership is not always the same. Individuals and cultures determine it. Therefore, the idea of what an effective leader should be is influenced not only by the personality of the individual but also by the cultural environment from which it originates.

According to Roll (2014) there is no single best style of leadership when organization are in different stage of growth, competitiveness and are staffed with employees with varying skills, abilities, personalities, motivations, experiences, age, cultural backgrounds. Leaders therefore should be versatile. In the different cultural environment of organizations, in an environment where employees have different cultural backgrounds, the most important issue that management has to deal with is the choice of an adequate way of managing subordinates.

At present days, in the wake of strong migration waves, Germany and Austria are questioning whether a multicultural society can work. (Wefersova 2017). Management must not only create an environment motivating to meet organizational goals, but it must also be an environment that promotes synergies in multicultural teams. Being an effective leader in a monocultural work environment still does not guarantee the same efficiency in a culturally diverse work environment. According to Meyer (2017) managers will need a multifaceted approach. They have to be informed enough and flexible enough to choose which style will work best in which cultural context and then deliberately decide how to adapt (or not) to get the results they need. Nowadays, the frequently discussed issue is how to combine the ability to foster co-operation between people of different cultures, while preserving ethical principles of behaviour. In this context, the debate is on ethical leadership. Other currently preferred leadership styles discussed in the business environment are: authentic leadership, participative leadership, charismatic or transformational leadership but also versatility leadership. Sven Hamrefors (2010) focuses attention on the communicative style of leadership, which enhances organizational efficiency, and P. G. Power (2004) speaks of emotionally intelligent leadership in his papers - based on Goleman's work. Here are the brief characteristics of each selected style of leadership:

Ethical leadership - we are talking about ethical leadership if the manager behaves in a manner that respects basic ethical principles. Organizational leadership should be able to recognize ethical issues, analyse them and take an opinion (Kals 2010). Brown and Treviño (2006) also dealt with the issue of ethical leadership. The authors point out that the ethical guidance of subordinates positively influences the ethical decision-making of subordinates, has a positive impact on their pro-social behaviour, job satisfaction, motivation and loyalty to the firm. Kanungo (2001) highlights the positive influence of ethical leadership on achieving organizational goals, benefits for the organization and its employees, and other stakeholders and society as a whole.

The idea of what is and is not ethical is determined by many factors. Significant factor is the personality of the individual, the society of which he is a part, the culture and his habits. In order for an organization to be able to apply ethical guidance to people, it is necessary to have not only managers with the appropriate personality profile but also the organizational 
conditions. According to DuBrin (2010) not only personal qualities (honesty, credibility, sincerity, friendliness, integrity of personality, fairness, justice, cooperation, etc.) are desirable, as well as organizational conditions - especially organizational culture with its values and norms accepting basic ethical principles. In addition, N. R. Vance (2011) considers organizational culture as one of four important organizational components that promote ethical behaviour and hence ethical leadership in an organization. The other three components are organizational structure, leadership and individual membership.

The most common barriers to the application of ethical approach to leadership can be seen in the personality of the manager, in the lack or absence of support for ethical principles in the management of managers. This is evidenced by the research of 810 respondents/managers (Remišova et al. 2015). According to the results of this particular research, the most important organizational factors determining the ethical leadership of the people in the organization are:

- ethical behaviour of the management of the organization 93.97\%,

- the ability to communicate openly at each level of management of any problems in the organization $-92.49 \%$,

- management clearly declares the requirement to observe the applicable laws $87.19 \%$,

- the organization requires respect for human rights $-86.82 \%$,

- the moral valuation of those who value the organization in practice $-85.71 \%$.

As well as ethical leadership, the transformational style of leadership is the required approach to leadership in the current generation entering a multicultural working environment. According to N. R. Vance (2011), this style strongly supports ethical behaviour, as it has open and direct communication, empowerment, responsibility, support for expressing different and innovative ideas. It can be said that these are the characteristics most urged by the current young generation. Many authors (e.g. Robbins and Judge 2011) emphasize that transformational leadership cannot be isolated from transactional leadership. Some basic characteristics of the transformational leaders are: inspiration of followers to overstep their own self-interest for the good of the organization, they are able to deeply influence and motivate their followers and to communicate effectively, gain respect and trust, encourage followers to be more innovative and creative, etc.

Charismatic leadership is linked to the personality characteristics of the leader, which lie primarily in his positive relationship with others, in the ability to motivate others to achieve vision. Charismatic leader is capable of communicating this vision with someone else. Many research show correlation between charismatic leadership and high performance. (Robbins, Judge 2011).

Authentic and participative leadership - authentic leaders are able to build trust, they are considered an highly ethical people. In the case of participatory leadership, employees are led towards responsibility, critical anticipation and selforganization. (Brown, Lent 2005). A participative style of leadership encourages employees to participate in decisionmaking and thus their co-responsibility; it increases autonomy and their ability to act independently. This has a positive impact on employees' internal interest and loyalty (House, 1996). According to Cooke et al. (2011) most top executives use a participatory style of leadership. This style is applied for two reasons. On the one hand, it is taken into account the political and geographical organization of the country where they operate and, on the other hand, top managers in national and multinational companies prefer delegation of authority, with the majority of decision-making processes shifting to lower levels of management. (Grancay et al. 2015). Leadership versatility - this style requires an ability to assess a situation accurately before applying the appropriate leadership style. (Roll 2014). As everywhere and in all the styles of leadership described above, there is always darker side to it. The art of managers is therefore to effectively use the positives of individual approaches to subordinates and their adequate application.

\section{Conclusion}

Effective global managers realize that the culture of the country affects corporate culture, how employees behave and how managerial functions are fulfilled. Managers also need to appreciate that the day-to-day business task differs between cultures (Solomon and Schell 2009). Culture significantly determines behavior patterns, perceptions attitudes, communication styles, labor relations etc. This is why different cultural work environment requires new ways how to lead subordinates, new managerial skills. However, a new generation requires new access to subordinates. Today's young people are no longer satisfied with dire management; it is not enough for them to meet orders without the possibility to express themselves often in not very optimal working conditions. Therefore, effective leadership style has also taken into account the demands of the current young generation most often greater autonomy, greater complexity in problem solving, greater co-participation in decision-making, compliance with ethical principles, W-L-B. The presented styles of leadership meet these requirements. These requirements should also be taken into account when training and educating future managers.

It is also necessary to emphasize that there is no single most effective leadership style. Each leadership style must reflect the specifics of individuals, specifics of the culture and context of 
the situation. Therefore, the manager must be able to combine leadership style.

As we have said, many studies have confirmed that there are prerequisites for effective leadership that can be learned and developed. We see the foundation in the development of emotional and cultural intelligence, in the development of social skills. In conclusion, we would also like to draw attention to the problem that managers face if they are sent abroad for a long time. It is a cultural shock that they undergo and which is also distracting them in their work. Even here, it is important that only those managers who have not only professional but also personal prerequisites and skills and who have gone through the preparation for such an activity abroad should be sent into this environment. Guirdham M. (1999) also points to the fact that as many as $70 \%$ of expatriates who failed abroad were sent abroad without adequate training. Proper preparation could reduce this number.

Although relevant literature can find relevant information on this issue, it cannot be said that managers are sufficiently prepared to operate in a global environment. Global managers should be educated, for example, also through educational programs at schools or in organizations themselves.

\section{References:}

- Byrd, M. (2007), "Educating and developing leaders of racially diverse organizations," in Human Resource Development Quarterly, 18(2), 275-279. $\underline{\text { Crossref }}$

- Brown, M. E. and Treviño, L. K. (2006), "Ethical leadership: A review and future directions," in The Leadership Quarterly, 17, 595-616. Crossref

- Brown, S. D. and Lent, R. W. (2005), Career Development and Counseling. Putting Theory and Research to Work. Malden, Oxford: John Wiley \& Sons.

- Cook et al. (2011), "HRM in emergent market economies: evidence and implications from Europe," in Human Resource Management Journal, Vol. 21, Issue 4, 2011, pp. 368-378. $\underline{\text { Crossref }}$

- DuBrin, A. J. (2010), Principles of leadership. USA: Cengage Learning. Goleman, D. (1998), Working with emotional intelligence. London: Bloomsbury.

- Goleman, D., R. Boyatzis and McKee, A. (2002), The new leaders: transforming the art of leadership into the science of results. London: Little Brown.

- Goleman, Daniel, "The Six Styles of Leadership". Retrieved from: https://intenseminimalism.com/2015/thesix-styles-of-leadership/

- Grancay, M. et. al. (2015), Gravity model of trade of the Czech and Slovak Republics 1995-2012: How have determinants of trade changed, in Politicka Ekonomie, Volume 63, (6), 759-777. Crossref

- Gutierrez, B., Spencer, S. M., and Zhu, G. (2012), "Thinking globally, leading locally: Chinese, Indian, and
Western leadership," in Cross Cultural Management: An International Journal, 19(1), 67-89. Hamrefors, S. (2010), "Communicative leadership," in Journal of Commnication Management, Vol. 14, Issue 2, 141-152. Crossref

- Hofstede, G. (1980), Culture's consequences: International differences in work - relates values. Beverly Hills: Sage.

- House, R. J. (1996), "Path-goal theory of leadership: Lessons, legacy, and reformulated theory, in The Leadership Quaterly, 7(3), 327. Crossref

- Kals, J. (2010), Script „Business Ethics“. Hochschule Ludwigshafen $20 \mathrm{~S}$. Retrieved from: http://www.fhlu.de/fb1/downloads/kals_MIM_BusinessEthics_Skript_S S2010.pdf.

- Kanungo, R. N. (2001), "Ethical values of transactional and transformational leaders," in Canadian Journal of Administrative Sciences, 18, 257-265. Crossref

- Kring, T. (2013), Generation Y - Anforderung an Personalund Organisationsentwicklung. Nr. 9.

- Montabaur: Akademie deutscher Genossenschaften.

- Maresova, P. (2010), Znalostní management v podniku. Zborník z Mezinárodnej vedeckej konferencie Hradecké ekonomické dny 2013. Hradec Králové: Gaudeamus.

- Meyer, E. (2017), Being the Boss in Brussels, Boston, and Beijing. Retrieved from: https://hbr.org/2017/07/being-theboss-in-brussels-boston-and-beijing.

- Power, P., G. (2003/2004), "Leadership for tomorrow: Once more, with feeling," in MT Eliza Business Review, summer/autumn. Retrieved from: https://atrium.haygroup.com/downloads/marketingps/ww/ PS_WW_Emotional_intelligence_leaders hip_for_tomorrow.pdf.

- Remisova et al. (2015), Ethical leadership in Slovak business environment. Bratislava: Wolters Kluwer Robbins, S. P. and Judge, T. A. (2011), Organizational behavior. New Jersey: Prentice Hall.

- Roy, S. R. (2012), "Digital mastery: The skills needed for effective virtual leadership," in International Journal of eCollaboration, 8(3), 56-66. Crossref

- Roll, Martin. (2014), "Versatility Is the Key To Effective Leadership". Retrieved from: https://martinroll.com/resources/articles/leadership/versatil ity-key-effective-leadership/.

- Rudy, J. et al. (2013), Manažment a organizačné správanie. Münster: MV-Wischenschaft. Schermerhorn, J. R. et al. (1991), Managing Organizational Behavior. New York: John Wiley \& Sons, Inc.

- Solomon, C., M. and Schell M. S. (2009), Managing across culture: the seven keys to doing business with a global mindset. USA: McGraw-Hill.

- Stier, J. (2006), "Internationalisation, intercultural communication and intercultural competence," in Journal of intercultural communication, 11, 2-12.

- Trelova, S. and Olsavsky, F. (2016), Linking theory with practice - perspective in preparing of vocational schools 
students in Slovakia. EDULEARN 16: Conference proceedings. Valencia: IATED Academy, 2016. P. 53305338. ISBN 978-84-608-8860-4. Crossref

- Thomas, D. C. and Inkson, K. (2003), Cultural Intelligence. San Francisco: Berrett-Koehler Publishers. Vance, N. R. and Harris, A. S. (2011), "Ethics as management principles" in Journal of leadership Accountability and Ethics, Vol. 8 (3), $11-21$.

- Wefersova, J. (2017), Problems of the German labour market. In: Hradec economic days, vol. 7, iss.1, Hradec economic days 2017. Hradec Kralove: University of Hradec Kralove, 2017. - P. 919-924.

- Wiesenfeld, B. M. et al. (2011), "Führung - Wann fair vorgeht, “ in Harvard Business Manager, (9), 10 - 12. 